\section{Urinary leukotriene e4 level profile in various degrees of severity in atopic dermatitis patients in dermatovenereology outpatient clinic Dr. Soetomo General Hospital, Surabaya: A descriptive study}

\author{
Meita Ardini Pratamasari, \\ M. Marsoedi Hoetomo, \\ Afif Nurul Hidayati
}

Dermatovenereology Departement

Medical Faculty of Airlangga

University/Dr. Soetomo General

Hospital Surabaya, East Java, Indonesia

\begin{abstract}
Atopic dermatitis (AD) is a chronic, relapsing skin inflammatory disease. Corticosteroid as the cornerstone treatment for $\mathrm{AD}$ has some flaw, especially for the chronic recalcitrant $\mathrm{AD}$, since it has side effects and high possibility of rebound. Leukotriene receptor antagonist (LTRA) which has been used for asthma and allergic rhinitis now has been developed for treating $\mathrm{AD}$, based on the similar mechanism of inflammation. Leukotriene (LT) is an inflammatory mediator that is thought to play role in the asthma, allergic rhinitis, and AD. Urinary leukotriene E4 (U-LTE4), the stable metabolite of LT, can be found in urine. This research aims to evaluate the role of LT in various degrees of severity in AD patients by measuring U-LTE4 levels using Enzyme Linked Immunosorbent Assay (ELISA). Twenty two AD patients who were in a flare state and came to the outpatient clinic on April - July 2017 were measured their U-LTE4 levels. The results demonstrated that mean of U-LTE4 levels increases consistently with intensity of the degree of severity, and this finding supports previous study that LT plays role in $\mathrm{AD}$.
\end{abstract}

\section{Introduction}

Atopic dermatitis (AD) is a chronic, relapsing skin inflammatory disease. The prevalence of $\mathrm{AD}$ in children is approximately $\quad 15-20 \%$, meanwhile prevalence of $\mathrm{AD}$ in adults is about $1-3 \%$ and both always increase over time. ${ }^{1}$ The incidence of $\mathrm{AD}$ in Dr. Soetomo General Hospital, Surabaya in 2013-2015 is $0.6 \%$ (327 patients) in adults, and 0.62\% (366 patients) in children, and also increase in each year. AD still becomes a substantial health problem recently, since the itchy sensation can cause lack of sleep and affect the patient's quality of life, and disease treatment costs much money. ${ }^{2}$ Leukotriene (LT), a potent inflammatory mediator which is derived from arachidonic acid in a pathway that involves 5-lipoxygenase (5LO), is believed to play a role in AD's pathogenesis as in asthma's and allergic rhinitis'. Those 3 diseases are known as the atopic triad. ${ }^{3}$ One of LT's classes, cysteinyl leukotriene (Cys-LT), which consists of LTC4, LTD4, and LTE4 is a potent mediator of inflammation. ${ }^{4,5}$ Cys-LT production increases substantially in association with allergic inflammation, likely reflecting the activation of mast cells and eosinophils in the lesional tissues. Urinary leukotriene E4 (U-LTE4) levels increase during asthma, allergic rhinitis, and AD. ${ }^{6}$ This finding is supported by previous studies that measured U-LTE4 levels in AD patients, and there was significant correlation between U-LTE4 levels and clinical symptoms (such as degree of severity) and also laboratory marker in AD such as Ig-E serum levels and absolute eosinophilic count. $3,4,7$

Corticosteroid is the cornerstone of AD's treatment line, but its use in chronic and recalcitrant $\mathrm{AD}$ becomes a challenge due to the side effects and high possibility of rebound. Leukotriene receptor antagonist (LTRA) has been used in asthma and allergic rhinitis treatments, and it has been introduced in $\mathrm{AD}{ }^{8}$ Some studies revealed that LTRA exhibited positive progression in subjective complaints, skin lesions, and eosinophilic cationic protein. ${ }^{9}$ U-LTE4 is the stable end product of LT metabolite, and excreted in the human urine. U-LTE4 is supposed to be reflecting the total body production of LT, because LTC4 and LTD4 are rapidly metabolized into LTE4. ${ }^{10}$ Urine examination is a non-invasive method than blood examination so we try to measure the levels in AD patients at our setting and see how the profile is, so that we can consider the use of LTRA in AD treatment.

\section{Materials and Methods}

This research was a descriptive study, using cross-sectional method to evaluate ULTE4 levels in various degrees of severity based on SCORAD index in AD patient. Samples of the study were all AD patients that came to Dermatovenereology Outpatient Clinic Dr. Soetomo General Hospital Surabaya, and were taken consecutively in 4 months (April 2017-July 2017). Inclusion criteria was in a flare or acute condition of $\mathrm{AD}$ skin lesion,
Correspondence: Afif Nurul Hidayati, Dermatology Venereology Dept, Faculty of Medicine, Universitas Airlangga - DR Soetomo Teaching Hospital, Jl. Mayjen. Prof. Dr. Moestopo, No. 47, Airlangga, Gubeng, Surabaya, Jawa Timur, 60286, Indonesia. Phone: +628123028024

E-mail: afif_nurulhidayati@fk.unair.ac.id

Key words: atopic dermatitis, urinary leukotriene E4 levels, degrees of severity

Contributions: The authors contributed equally.

Conflict of interest: the authors declare no potential conflict of interest.

Received for publication: 1 February 2019. Accepted for publication: 13 February 2019.

This work is licensed under a Creative Commons Attribution-NonCommercial 4.0 International License (CC BY-NC 4.0).

(C) Copyright M.A. Pratamasari et al., 2019 Licensee PAGEPress, Italy

Dermatology Reports 2019; 11(s1):8061

doi:10.4081/dr.2019.8061

diagnosed by Williams criteria. Patients who were in corticosteroid treatment in the last 2 weeks, antihistamin treatment in the last 1 week, and other antiinflamation or immunosuppressant treatment include LTRA in the last 4 weeks were excluded from the study. Other exclusion criterias were patients with asthma or allergic rhinitis history, patients who were in the acute phase of allergic or inflammation disease, have kidney disfunction, smokers or in pregnant condition since it can affect the U-LTE4 levels.

Informed consent was obtained from the patients or the parents if the patient was a child. Then the patients diagnosed according to Williams criteria, subjected to history taking, clinical examination, and determined their degrees of severity according to SCORAD index. After that urine sample was taken, then centrifuged and stored in $-80^{\circ} \mathrm{C}$ freezer until the study period had finished. Then all urine samples were measured its U-LTE4 levels by double-antibody sandwich enzyme-linked immunosorbent assay (ELISA) technique, with Human Leukotriene E4 ELISA Kit reagent from Shanghai Crystal Biotech Co., LTD using Humareader ${ }^{\circledR}$ Single. Data are expressed as mean \pm SD. No analysis test are performed since this was a descriptive study. Ethical clearance had been approved for this study by the Ethical Committee in the hospital. 


\section{Results}

This research involved total $22 \mathrm{AD}$ patients in Dermatovenereology Outpatient Clinic General Hospital Surabaya. They were 7 males and 15 females, and their age ranged between 2-51 years old with a mean age of $17.16 \pm 13,61$ years old. There were 8 patients $(36.36 \%)$ with mild degree of AD based on SCORAD index, 11 patients $(50.00 \%)$ with moderate degree, and 3 patients $(13.64 \%)$ with severe degree. The mean of U-LTE4 levels in total subjects was $24.02 \pm 11.02 \mathrm{pg} / \mathrm{ml}$, meanwhile the mean of U-LTE4 levels in mild, moderate, and severe AD based on SCORAD index were $16.43 \pm 8.01 \mathrm{pg} / \mathrm{ml}, 27.45 \pm 9.35 \mathrm{pg} / \mathrm{ml}$, and $31.70 \pm 15.17 \mathrm{pg} / \mathrm{ml}$, respectively (Figure 1). The least U-LTE4 level in the samples was $1.2 \mathrm{pg} / \mathrm{ml}$ and was found in mild AD group, otherwise the greatest was $41.1 \mathrm{pg} / \mathrm{ml}$ and belonged to severe AD group. Table 1 shows that the mean of U-LTE4 levels in each degree of severity are higher in accordance with degree of severity.

\section{Discussion}

The purpose of U-LTE4 level measurement is to know the representative of Cys-LT production as inflammatory marker in vivo. ${ }^{3,4}$ Results of this study showed that more severe the degree of severity, the mean of U-LTE4 level were increased. This increasing production of Cys-LT might be caused by increasing immune cells that produce Cys-LT, which are mast cells, basophils, eosinophils, and macrophages. ${ }^{11}$ Same observations were reported by Miyoshi et al (1999), Emam et al (2003), Hon et al (2004), and Fathi et al (2007), who concluded that U-LTE4 in moderate and severe degree of $\mathrm{AD}$ were significantly higher than the mild degree. They also stated that U-LTE4 levels in AD patients were higher significantly rather than the control subjects. ${ }^{3,12,13}$ Hishinuma et al also reported that U-LTE4 levels in AD patients were significantly higher than nonAD patient. ${ }^{4}$ This study didn't use controls since we only want to know about the profile of U-LTE4 levels in each degree of severity of $\mathrm{AD}$, whether increase or not.

U-LTE4 is a marker of Cys-LT production in vivo, since LTC4 and LTD4 are rapidly metabolised into LTE4 and also rapidly excreted in the urine. ${ }^{11}$ Growing evidence suggests that leukotrienes play an important role in the pathogenesis of bronchial asthma and allergic rhinitis. They cause smooth muscle contraction, impair mucocilliary clearance, enhance mucus secretion, attract eosinophils to the airways, and increase vascular permeability producing edema. Spector et al reported that LTRA treatment could decrease day and night asthma symptoms, less frequent use of short-acting $\beta_{2}$-agonist on demand, and higher values of evening lung function parameters $\left(\mathrm{FEV}_{1}\right.$ and $\mathrm{PEF}$ rate). ${ }^{14} \mathrm{AD}$, along with bronchial asthma and allergic rhinitis, are known as the atopic triad. Some studies has reported rational evidence of LTRA use in AD, however, its exact mechanism of action in AD hasn't been established yet. ${ }^{15}$

$\mathrm{AD}$ is a disease that is influenced by multifactorial entity, so we shouldn't only depend on the leukotriene as the exact cause of AD exacerbation. This U-LTE4 level measurement might be considered in $\mathrm{AD}$ chronic patient who is recalcitrant to other treatments, and could be used before someone decides to take LTRA treatment since this is such a pricey drug. This study has some limitations, so that continued studies on this subject should be conducted, such as study to determine the U-LTE4 cutoff value in Indonesia since it has never been done. Other studies in primary health settings to get more subjects also should be done, and so should the studies that compare other clinical parameters in $\mathrm{AD}$ with U-LTE4 levels such as total IgE serum levels. Other limitation of this study is that we didn't measure the urine creatinine because we only want to see the profile in each degree of severity.

\section{Conclusions}

Our findings support other studies that LT plays role in AD, so the use of LTRA might be considered especially in chronic $\mathrm{AD}$ patient who is recalcitrant to any other modalities. Other study that use analytic design still needs to be perform later, so it could demonstrate the relation between $\mathrm{U}$ LTE4 levels and AD degree of severity statistically. Study that compares other laboratoric parameters such as total $\operatorname{IgE}$ serum is also needed.

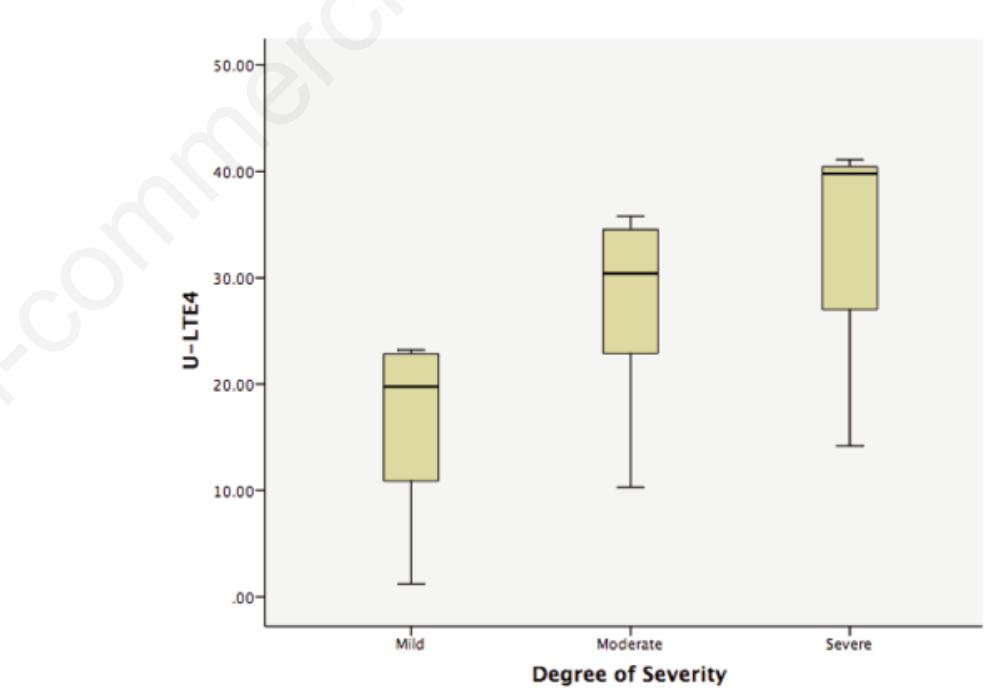

Figure 1. U-LTE4 levels distribution based on degrees of severity (SCORAD index) in box-plot.

Table 1. U-LTE4 levels profile based on degrees of severity in the study subjects $(n=22)$.

\begin{tabular}{|c|c|c|c|c|c|}
\hline Degrees of severity & $\begin{array}{c}\text { Number } \\
\text { (Percentage) }\end{array}$ & $\begin{array}{c}\text { Mean of SCORAD } \\
\text { index }\end{array}$ & $\begin{array}{l}\text { Minimum value } \\
(\mathrm{pg} / \mathrm{ml})\end{array}$ & $\begin{array}{l}\text { Maksimum value } \\
(\mathrm{pg} / \mathrm{ml})\end{array}$ & $\begin{array}{c}\text { Mean } \pm \text { SD } \\
(\mathrm{pg} / \mathrm{ml})\end{array}$ \\
\hline Mild & $8(36.36 \%)$ & $20.58 \pm 4.02$ & 1,2 & 23,2 & $16,43 \pm 8,01$ \\
\hline Moderate & $11(50.00 \%)$ & $34.82 \pm 4.29$ & 10,3 & 35,8 & $27,45 \pm 9,35$ \\
\hline Severe & $3(13.64 \%)$ & $58.13 \pm 3.35$ & 14,2 & 41,1 & $31,70 \pm 15,17$ \\
\hline Total & 22 & & & & \\
\hline
\end{tabular}




\section{References}

1. Leung DYM, Eichenfield LF, Boguniewicz M. Atopic dermatitis (Atopic eczema). In: Goldsmith LA, Katz SI, Gilchrest BA, Paller AS, Leffel DJ, Wolff K, editors. Fitzpatrick's dermatology in general medicine. 8th ed. New York: McGraw-Hill; 2012. p.16582.

2. Nutten S. Atopic dermatitis: global epidemiology and risk factors. Ann Nutr Metab 2015; 66(suppl 1): 8-16.

3. Fathi G, Saber K, Shaaban F, Fakhry D. Increased urinary leukotriene E4 and its correlation to severity and laboratory markers of atopic dermatitis in children. J Med Sci 2007; 7(2): 216-21.

4. Hishinuma T, Suzuki N, Aiba S, Tagami $\mathrm{H}$, Mizugaki M. Increased urinary leukotriene E4 excretion in patients with atopic dermatitis. Br J Dermatol 2001; 144: 19-23.

5. Liu M, Yokomizo T. The role of leukotrienes in allergic diseases. Allergol Int 2015; 64: 17-26.

6. Kanaoka Y, Boyce JA. Cysteinyl leukotrienes and their receptors, emerging concepts. Allergy Asthma Immunol Res 2014; 6(4): 288-95.

7. Adamek-Guzik T, Guzik TJ, Czerniawska-Mysik G, Korpanty G, Mastalerz L, Radwan J, et al. Urinary leukotriene levels are increased during atopic eczema/dermatitis syndrome, relation to clinical status. Allergy 2002; 57: 732-6.

8. Mastalerz L, Kumik J. Antileukotriene drugs in the treatment of asthma. Pol Arch Med Wewn 2010; 120(3): 103-8.

9. Eustachio N, D’Erasmo M, Di Leo E, Calogiuri G, Montinaro V, Ferrannini A, et al. The employment of leukotriene antagonists in cutaneous diseases belonging to allergological field. Mediators Inflamm (serial online) 2010 [cited on 2016 Aug 30]; [6 screens]. Available from: https://www.hindawi. com/journals/mi/2010/628171/

10. Sala A, Voelkel N, Maclouf J, Murphy RC. Leukotriene E4 elimination and metabolism in normal human subjects. J Biol Chem 1990; 265(35): 21771-8.

11. Haeggström JZ, Funk CD.
Lipoxygenase and leukotriene pathways: biochemistry, biology, and roles in disease. Chem Rev 2011; 111: 586698.

12. Hon KLE, Leung TF, Ma KC, Li AM, Wong Y, Li CY, et al. Urinary leukotriene E4 correlates with severity of atopic dermatitis in children. Clin Exp Dermatol 2004; 29: 277-81.

13. Emam EK, Salem SAM, Fouad DA. Study of urinary leukotriene E4 in atopic dermatitis: relation to disease severity. Egypt J Pediatr Allergy Immunol 2003; 1(2): 134-9.

14. Mastalerz L, Kumik J. Antileukotriene drugs in the treatment of asthma. Pol Arch Med Wewn 2010; 120(3): 103-8.

15. Eustachio N, D'Erasmo M, Di Leo E, Calogiuri G, Montinaro V, Ferrannini A, et al. The employment of leukotriene antagonists in cutaneous diseases belonging to allergological field. Mediators Inflamm (serial online) 2010 [cited on 2016 Aug 30]; [6 screens]. Available from: https://www. hindawi.com/journals/mi/2010/628171/ 